\title{
Left melodrama
}

\author{
Elisabeth Anker \\ Department of American Studies, George Washington University, Washington DC 20052, USA.
}

\begin{abstract}
Left melodrama' is a form of contemporary political critique that combines thematic elements and narrative structures of the melodramatic genre with a political perspective grounded in a left theoretical tradition, fusing them to dramatically interrogate oppressive social structures and unequal relations of power. It is also a new form of what Walter Benjamin called 'left melancholy', a critique that deadens what it examines by employing outdated and insufficient analyses to current exploitations. Left melodrama is melancholic insofar as its use of older leftist critical methods disavows its attachments to the failed promises of left political-theoretical critique: that it could provide direct means to freedom and moral rightness. Left melodrama is melodramatic insofar as it incorporates the specific melodramatic narrative, style and promise of the text that stands in for its disavowed attachments: the Manifesto of the Communist Party. Whereas the Manifesto's critical power promised radical political transformation, left melodrama incorporates the Manifesto's melodramatic style in an effort to revivify that promise. It thus inhibits the creation of new critical methods appropriate to our current historical moment and occludes Marx and Engels' warning that the possibility of radical transformation is diminished when the past furnishes the vision for the future. Left melodrama can be found in the texts of Giorgio Agamben, Michael Hardt and Antonio Negri; their reincorporation of the Manifesto's melodrama both contributes to their widespread success and undercuts their critical capacities to examine and challenge the inequalities, injustices and unfreedom that shape the present moment.

Contemporary Political Theory (2012) 11, 130-152. doi:10.1057/cpt.2011.10; published online 26 July 2011
\end{abstract}

Keywords: left politics; melancholy; melodrama; The Communist Manifesto; Giorgio Agamben; Michael Hardt and Antonio Negri

This essay is concerned with a type of contemporary political theory that has become exceedingly popular in recent decades. Exemplary practitioners include Michael Hardt, Antonio Negri and Giorgio Agamben, writers whose work has captured the interest of a generation of scholars, as well as the interest of a reading public broader than that enjoyed by most academics. This work combines the narrative structure and thematic elements of the melodramatic

(C) 2012 Macmillan Publishers Ltd. 1470-8914 Contemporary Political Theory Vol. 11, 2, 130-152 www.palgrave-journals.com/cpt/ 
genre found in literary and cinematic texts with a political perspective grounded in a left theoretical tradition, fusing them into a form of critique that dramatically interrogates oppressive social structures and unequal relations of power. I call this critical form 'Left Melodrama'.

Political-theoretical analysis in left melodrama unfolds within a heightened drama that employs categorizations of villainy and victimhood, cycles of pathos and action, and a moral economy of good and evil to organize its critical inquiry. Left melodrama's appeal derives from the moral clarity it confers on difficult situations, the virtuous power it bestows upon subjugation and the assurance it offers that heroic emancipation can conquer the villainous source of oppression. Although left melodrama intends to galvanize its audience for social change, its conventions limit its capacity to depict the distinct challenges and unintended effects of political life.

Left melodrama is a recent form of political theory, but it recapitulates an older dynamic that Walter Benjamin (2005) called 'left melancholy'. Left melancholy, according to Benjamin, is a type of leftist critique that deadens what it examines because it employs analyses that are both insufficient and outdated in relation to current inequalities and exploitations. Left melodrama stems from left melancholy in part because its analytic methods undercut and subvert a critical grasp of the objects it places under scrutiny. Its melancholic dynamic, however, is both deeper and more specific than this. Melancholy is defined as a refusal to acknowledge one's desire to re-possess something that has been loved and lost. Left melodrama is melancholic insofar as it disavows its attachments to the failed but still loved promise of leftist politicaltheoretical critique: that it could provide direct means to freedom and moral rightness. In other words, left melodrama is underpinned by a refusal to acknowledge the loss of left political theory's guarantee that it provides a means to revolutionary freedom, as well as the loss of intrinsic moral virtue implicitly granted to its practitioners. More subtly, it is melancholic because it incorporates the particular melodramatic narrative, style and promise of the Manifesto of the Communist Party. The Manifesto is a paradigmatic text for left melodrama, as it comes to represent what the left has desired and lost: the guarantee of immanent freedom, the clear virtue of leftist political positions and the promise of the left's destiny as the harbinger of revolutionary emancipation. Left melodrama recapitulates the Manifesto's melodramatic style in a melancholic effort to hold on to and revivify these losses. While left melodrama's incorporation of the Manifesto's melodrama can offer an affectively charged narrative that lucidly reveals the violence of oppression, its critical capacities and effective diagnostics are curtailed by the very methods it employs in that effort.

The current appropriation of the Manifesto's melodramatic form, I argue, inhibits the creation of new critical methods appropriate for analyzing the 
present and occludes Marx and Engels' own counsel that the possibility of radical transformation is diminished when the past furnishes the blueprint for the future. For Marx and Engels, only when visions of the future are open-ended can they remain unburdened by the structural and imaginative limitations of the present. In this essay I make the argument for left melodrama in three parts, beginning with an analysis of Benjamin's concept of left melancholy and its application to left melodrama. I then analyze the melodramatic structure and form of the Manifesto itself. In the third part of the essay, I combine these analyses to examine how the current left melodramas of Hardt, Negri and Agamben melancholically recapitulate the Manifesto's melodrama, and I emphasize what is lost for leftist inquiry in this process. Contemporary left melodrama entrenches the deadening effects of left melancholy, and thus impedes political theoretical efforts to challenge the specific forms of inequality, injustice and unfreedom that shape our present era.

\section{Left Melancholy and Political Critique}

Walter Benjamin once penned a brief, scathing critique of left intellectuals whose writings seemed only to reinforce the exploitation they placed under interrogation. He derided the way their condemnations of society derived from habitual modes of criticism rather than a real desire for change, and became reflex responses imposed upon difficult problems. Erich Kastner, the particular Weimar-era writer who served as an exemplar of this broader condition, was 'as incapable of striking the dispossessed with his rebellious accents as he is of touching the industrialists with his irony' (Benjamin, 2005, pp. 423-424). Kastner's routinized forms of scrutiny betrayed a longing for the comfort of past sureties that precluded insight into present configurations of power and inequality, and thus stifled possibilities for more radical political action.

Benjamin titled his critique 'Left Melancholy' though he did not provide an explicit definition of the term in the text. It is provocatively contoured, however, as a 'clenched fist in papier-mâché': a figure that outwardly gestures to revolutionary desire yet is reified, inanimate, frozen in place at the same time that it has no inside material (2005, p. 424). Its core contains only 'empty spaces', 'hollow forms', an inner void where melancholy holds on to dead objects instead of engaging the world of animate life, even and especially when that world is increasingly oppressive, commodified, fascist and in desperate need of radical social transformation to real equality and freedom (2005, p. 425).

Benjamin's term 'Left melancholy' seems to imply not only the act of holding on to dead objects - the more conventional way of interpreting melancholy after Freud - but the frightening act of deadening live subjects in its grasp. 
In The Origin of German Tragic Drama, where Benjamin engages more directly in the concept of melancholy, he describes it in one iteration as "the deadening of the emotions ... [that] can increase the distance between the self and the surrounding world to the point of alienation from the body' (Benjamin, 2003, p. 140). Melancholy's deadening work creates distance between the self and the world it places under investigation, an act that can potentially provoke distanciation and enable innovative criticism, but that also harbors the dangerous threat of devitalizing that very world. In melancholy, 'the utensils of active life are lying around unused on the floor, as objects of contemplation' (2003, p. 140). Melancholy, in this regard, is a form of contemplation that makes alien the things in the world; in the particulars of left melancholy, this making-alien turns active material into unused, inert objects. ${ }^{1}$ In 'Left Melancholy' Benjamin similarly describes Kastner's intellectual movement as accomplishing 'the transposition of revolutionary reflexes ... into objects of distraction, of amusement, which can be supplied for consumption' (2005, p. 424). Left melancholy is akin to a process of reification, as habituated forms of leftist scrutiny drain the vitality and energetics of both the melancholic and the objects he holds on to, vitality necessary for sustaining the critical push for freedom in a dark and dangerous time. Diminishing revolutionary potential, left melancholy reflects the outward trappings that signify work for social change while its animating core is inert, empty and lifeless.

At the end of the twentieth century Wendy Brown revisited 'Left Melancholy' to ask how Benjamin's analysis could supply a diagnosis for the contemporary moment. In 'Resisting Left Melancholy' Brown (1999) argues that loss now saturates leftist intellectual inquiry, as leftist academics must contend with the loss of legitimacy for Marxism and socialism, the loss of a unified movement and method and the loss of viable alternatives to counter the nexus of liberal-capitalism. These losses originate in part in leftist critical analysis, which has had difficulty accounting for recent formations of power and thus has become ineffective in challenging them. For Brown, the difficulty in analyzing contemporary power is traceable to new iterations of left melancholy. She addresses unanswered questions from Benjamin's piece by examining the content of the losses that left melancholy clings to, and by asking how left melancholy accomplishes its deadening work. Addressing the latter question first, she suggests that deadening arises from the conventional methodologies of left critical theory: economic determinism, totalizing social analysis and a teleology of human emancipation have each proven inadequate or unsustainable for grappling with the current conditions of contemporary politics. Significant historical shifts have changed how politics and the economy operate and interconnect with individuals since the mid-nineteenth century, but leftist modes of critique have often been unable to keep pace with them. Drawing from Stuart Hall (1988), Brown argues that attachments 
to older forms of critique narrow and devitalize the current dynamics they scrutinize, and thus impede discovery of the unexpected and particular. A more effective analysis would require a break with certain methods and assumptions that had conventionally defined what it meant to be part of the academic left.

Yet attachments to outdated forms of critique are only one part of the problem, and they had already been confronted by key interventions from feminist theory, queer studies and post-colonial studies among other modes of inquiry. More influential, Brown suggests, is the loss that underpins the attachments: 'In the hollow core of all these losses, perhaps in the place of our political unconscious, is there also an unavowed loss - the promise that left analysis and left commitment would supply its adherents a clear and certain path toward the good, the right, and the true?' (1999, p. 22). Melancholy, in Sigmund Freud's 'Mourning and Melancholia', is defined as the loss of what cannot be loved, the disavowed desire for something that has left or abandoned the subject. It is the refusal to acknowledge that a 'love object' has been lost, or that one had desired this lost object in the first place (Freud, 1959). Incorporating Freud's analysis, Brown argues that left melancholy is formed by the refusal to acknowledge the desire for what the left has lost: the faith that leftist theoretical analysis and political commitment can provide a direct means to truth, moral virtue and human freedom. This 'hollow core' of loss, perhaps the core of Benjamin's papier-mâché fist, underpins left critical theory, and because unacknowledged it continues to inhibit the academic left's reckoning with the present; it weakens and marginalizes leftist inquiry. The refusal to relinquish these desires, let alone acknowledge them, marks the refusal to grapple with the failed promise of inevitable emancipation, or as Hall puts it, the refusal to abandon the guarantee that leftist theory can 'rescue us from the vicissitudes of the present' (Hall, 1988, p. 4). Both Brown and Hall insist that the unsettling and difficult practice of self-critique can begin to undo some of these attachments and counter the disavowals of left melancholy. Sustaining leftist commitments paradoxically requires acknowledging the left's losses and failures.

In the decade since Brown made her analysis, the topics, range and methods of left analysis have further expanded and reoriented crucial aspects of critical thought. Widespread criticisms of America's post-9/11 politics reinvigorated leftist critical and political theory and remobilized its sustained commitment to social transformation. Influential authors in American academic circles, such as Giorgio Agamben, have written trenchant political critiques of contemporary domination that did not privilege only class or capital in diagnosing experiences of unfreedom. Others, such as Michael Hardt and Antonio Negri, have used multidisciplinary analyses to delineate complex formations of power and energize revolutionary sentiment. Do these changes demonstrate that melancholy has 
loosened its hold on leftist intellectual scrutiny? The answer to this question, I offer, is no. The attachments animating left melancholy are still present in particular modes of left theoretical work, though they have been reinscribed in new form.

Left melancholy continues to shape a type of left political-theoretical inquiry, but the loss it holds onto is more specific than the earlier types Benjamin and Brown diagnosed and manifests in different form, even as it draws from the dynamics Benjamin and Brown identify. Current left melancholy marks the loss of a particular love object. Freud's analysis of melancholy can help to interpret the nature of this object. Freud makes clear that the lost 'object' - his psychoanalytic term for describing what or who is desired - can be a person, a group identity, an abstraction, a country or an ideal (Freud, 1959, 1990). ${ }^{2}$ The melancholic not only refuses to acknowledge that it has lost or been abandoned by the object it loves. It also takes on the characteristics of the lost love object. The melancholic subject incorporates the disavowed lost object into itself in order to hold on to what it has lost (Butler, 1997). Melancholy, therefore, includes both a disavowal of loss, and a part of the self that turns into that very object, so that the self begins to mimic the lost object of its desire. Through incorporation, the melancholic refuses to let its object go.

The lost object, in current left melancholy, is a paradigmatic text that has been weighted with representing the set of losses articulated above. It is a text that provoked the promise and the dream of radical social transformation, that augured revolution, indeed that founded left praxis, all of which can now seem lost, failed and out of reach. Most important, this text galvanized millions of people, and its widespread appeal, explosive moral power and emancipatory guarantee engendered a century or more of transnational solidarity toward the project of human freedom.

\section{The lost object: The Manifesto of the Communist Party}

In certain strands of contemporary critical theory, I am suggesting, the Manifesto has become the 'hollow core', the lost and deadened object. Its style and terms of analysis are reabsorbed into contemporary political inquiry as a way of fending off the losses it represents. The Manifesto is 'lost' to the degree that it stands in for the failed twinned promises of leftist critical theory: inevitable emancipation and unwavering moral rightness. In this new form of critical theory, the Manifesto represents a former era when leftist political critique seemed unquestionably vital and promising, when the moral virtue of left critique seemed valid, when the freedom it envisioned seemed imminent. 
Indeed the Manifesto, when situated in this way, becomes the instantiation of those guarantees. The logic of the Manifesto as the lost love object conjures up a past era when the left's moral certitude seemed self-evident, and aims to recover the possibility that a single text can energize populations for the collective pursuit of human freedom. ${ }^{3}$ The Manifesto also represents these failed promises because the collective movements it engendered often only entrenched the oppression they intended to overcome.

While this new form of left melancholy still interprets politics through older leftist frameworks, including monocausality, teleology and moral certainty, it displaces the earlier analytic targets of capital, revolution, immanent dialectic and the working class onto different targets. And more strikingly, left melancholy now adopts the galvanizing narrative form the Manifesto uses to tell its story. Left inquiry draws upon the Manifesto's particularly melodramatic narrative form. Melodrama, I offer, shapes the foundational text that provides a key framework for left political analysis. What I call 'left melodrama' is a new form of left melancholy that holds on to the Manifesto's promises by incorporating the Manifesto's melodramatic narrative and style into its very constitution. The Manifesto's melodrama is melancholically absorbed into some of the most popular critical theory in left academe, particularly the work of Agamben, Hardt and Negri. In the rest of this essay, I first outline certain melodramatic conventions and detail the particular form melodrama takes in the Manifesto. I then examine how the Manifesto's melodramatic tropes melancholically inhabit the left melodrama of contemporary critical theory.

Melodramas, while varying to a certain degree across time, place and medium, generally portray events through a narrative of victimization and retribution, and a character triad of villain, victim and hero (Elsaesser, 1987; Gledhill, 1987; Neale, 1993; Brooks, 1995; Williams, 1998, 2001; Mulvey, 2009). Their stories are organized in cycles of injury and action, of suffering and strength, until a hero rescues the victim and usually triumphs over the villain. ${ }^{4}$ Melodramas encourage visceral responses in their readers and audiences by depicting wrenching and perilous situations that aim to generate affective connections to victims and the heroes who rescue them. Using a morally polarizing worldview, melodramas signify goodness in the suffering of victims, and signify evil in the cruel ferocity of antagonists. The victim's injury at the core of the narrative divides the world and demands retribution or redemption as response. Many melodramas promise a teleology of change that can rectify the social injuries they diagnose. They valorize the powerless and vilify the powerful, even though the types of characters who are powerless or powerful can shift radically in different texts and historic junctures; within melodramas, human actions are often dictated by social position, indeed individual characters are often the metonymic substitute for economic or social classes.

136 (C) 2012 Macmillan Publishers Ltd. 1470-8914 Contemporary Political Theory Vol. 11, 2, 130-152 
Melodramatic political arguments might at first blush seem to be the purview of the right, especially in their contemporary political manifestations: certain melodramatic tenets, including polarizing camps of good and evil, promises of virtuous overcoming of villainy and moral righteousness, are in tune with the reactionary and anti-intellectual rhetoric of Reagan and Bush, Tea Parties and Glenn Beck (Anker, 2005). Yet melodrama is politically promiscuous, not aligned with one particular agenda. In fact melodramatic cultural forms, particularly theater, have aligned with left politics for over two centuries. Early melodramatic plays dramatized and moralized unequal social-economic relations, connecting poverty with virtue and wealth with venality (Elsaesser, 1987; Brooks, 1995; Buckley, 2006). They historically favored the cause of the dispossessed rather than those who held power, and their heroes were often those harmed by a bourgeois economy (Gledhill, 1987). The imbrication of melodrama and revolution is well-documented by theater historians and literature scholars, as many Euro-American leftists have at key points turned to melodrama 'as the most effective means of conveying revolutionary sentiments to mass audiences' (Gerould, 1994, p. 185). Indeed, Jean-Jacques Rousseau invented the term 'melodrama' and posthumously inspired melodramatic critiques of unjust authority and class inequality in revolutionary France (Rousseau, 1990, p. 497). In the 1830s French and English melodrama contributed to shaping the organizing narratives of the working class and the consciousness of social injustice. One French melodramatist even claimed that his plays organized the 1848 revolution (Gerould, 1994, p. 186). After the Bolshevik revolution, Soviet leftists created and subsidized a particularly expressionist form of melodramatic theater and film, and proclaimed melodrama to be the most effective cultural form to explain revolutionary ideology (Pryzbos and Gerould, 1980). ${ }^{5}$ In mid-twentieth century America, a differently organized and more pessimistic form of melodramatic theatricality infused left sensibilities in the films of Douglas Sirk. For later film scholars, Sirk's Marxist critiques of capitalism and gender norms played out in the tawdriness and excess of his films' mise-en-scène; his films unmasked various forms of oppression using disheartening storylines permeated by alienation and depression (Elsaesser, 1987; Mulvey, 2009).

Yet in addition to melodrama's better-known leftist theatrical and film affiliations, I contend that melodrama also contributes to the political inquiry that structures the Manifesto of the Communist Party. Karl Marx and Friedrich Engels can be considered melodramatists in penning their challenge for collective emancipation. Reading the Manifesto as melodrama shows how the text illuminates class oppression by molding historical relations into stark binaries, detailing the unjust suffering of the proletariat, promising the triumph of heroism, highlighting the moral righteousness of the oppressed and 
employing all of these tropes with the aim to affectively motivate its reader into revolutionary action.

\section{Manifesto Melodrama}

The Manifesto of the Communist Party takes shape through a melodramatic narrative that connects revolutionary heroism with the social victimization of the proletariat, in order to both illuminate the violence of industrial capital and reveal its immanent overcoming. The presumable intentions of the text - to point to the economic forces that drive political and historical development, to motivate radical action to establish an equal, sustainable and meaningful species-wide human existence - also turn the complex dynamism of history into a melodramatic unfolding. The Manifesto promises the radical overcoming of economic domination, and like most melodramas, insists that rightness will eventually prevail. Even for all of Marx's and Engels' claims to the contrary, they still reassure their readers that the world is just: oppression will be eradicated and the oppressed will triumph.

Marx and Engels begin section one of the Manifesto by arguing,

The history of all hitherto existing society is the history of class struggles.

Freedman and slave, patrician and plebian, lord and serf, guild master and journeyman - in a word, oppressor and oppressed - stood in constant opposition to one another, carried on an uninterrupted, now hidden, now open fight, a fight that each time ended either in a revolutionary reconstitution of society at large, or in the common ruin of the contending classes. $\left(1978\right.$, pp. 473-474) ${ }^{6}$

From the outset of the text, Marx and Engels reconfigure the history of social relations into various binary oppositions, which all become an opposition of 'oppressor and oppressed'. This opposition is not particularly civilizational, nor does it seem to partake in longstanding Greek/barbarian distinctions based on superiority. And neither does it seem to be a product of an ontological friend/enemy antagonism, even though Carl Schmitt melodramatically describes it as such: 'This antithesis concentrates all antagonisms of world history into one single final battle against the last enemy of humanity' (1996, p. 74). Rather, this is a distinction that is specifically based on power. It is what Marx and Engels explicitly describe as having become a 'simplified' polarity, juxtaposing two options: powerful and powerless, in which power is determined by economic production (1978, p. 474). For the authors, the modern industrial era has tidied the pre-modern clutter of human relationships into 'two great hostile camps, into two great classes directly facing each other: 
Bourgeoisie and Proletariat' (1978, p. 474). They create their contemporary moment as a sharpening of hostility down to solitary and stark distinctions. These two classes do not merely face each other, but they do so, as the authors state above, 'directly'. This language heightens the back-and-forth drama of this clash of power - what film scholar Linda Williams calls melodrama's 'dialectic of pathos and action' - that is part of melodrama's affective engagement with its readers (2001, p. 30). For Marx and Engels, relations of power, even 'political power, properly so called, is merely the organized power of one class for oppressing another' (1978, p. 490). These first sentences inaugurate history as a dramatic narrative story about power antagonisms - a building up and compressing of myriad human relationships into one model with two possible positions.

The analysis of this power antagonism does not rest there, however; if read through the generic conventions of melodrama, it is moralized. The binary Marx and Engels identify is 'oppressor and oppressed' (1978, p. 474). Another way to explain this might be to say that it is a distinction based upon villainy and victimization; in melodrama, the experience of oppression by oppressor is depicted by categories of victim and victimizer, with victimization intensified by the unjustness of the injury. Oppression marks the inverse link between power and moral virtue, so that more of one entails less of the other. If we understand moralization as the overt making of absolute moral claims, then the authors do not explicitly moralize their distinction, nor is their critique reproachful or self-satisfied (Bennett and Shapiro, 2002). However, they do interpret history by drawing on distinctions that have deep-seated moralistic connotations. They do not make direct claims of goodness for the proletariat but they do describe the proletariat's condition in heightened language that gestures to an organizing structure of good and evil, and they frame events in a cyclical narrative of victimization and overcoming. In these ways, the Manifesto signals the melodramatic claim that powerlessness marks virtue. Writing in the 1940s, literary critic Wylie Sypher (1948) argued that Marx uses melodramatic tropes throughout Capital. Sypher suggested that Marx's particular uptake of the Hegelian dialectic draws partly from melodrama's Manichean moral binary. For Sypher, the social conventions of the nineteenth century were saturated with melodramatic ways of viewing the world; Marx is a product of his time period, and though not intentionally employing melodramatic conventions he would have been hard pressed to fully extricate himself from melodrama's pervasiveness as a worldview. Though Sypher's claims for melodrama's saturation may be overdrawn, his analysis supports how the Manifesto can be read to employ melodrama's moralistic tropes in its depiction of revolution. The Manifesto's initial paragraphs draw upon the moral horrors of capital to presage the Communist revolution, and they shape how readers interpret the rest of the powerful first section.

(C) 2012 Macmillan Publishers Ltd. 1470-8914 Contemporary Political Theory Vol. 11, 2, 130-152 139 
In arguing that the bourgeoisie acquires power by conquering all other classes, Marx and Engels diagnose one primary mover of modern history, one that subtends and subsumes other forces: capital. They isolate capital in order to draw attention to its pervasive force, and they place it above and in control of other social forces, which become its derivatives. Capital, and the bourgeoisie as the capitalist class, produces the political, social, familial dilemmas that the Manifesto diagnoses. Even the state is wholly in the service of modern industry. The bourgeoisie puts an end to all other human relations besides those based on exchange and labor; dramatically, it has 'pitilessly torn asunder' feudal ties, leaving only 'naked self-interest', 'callous cash-payment' (Marx and Engels, 1978, p. 475). Its actions are quite violent: toward all other human relations, it has 'drowned', 'destroyed', 'stripped of its halo' and 'torn away' their organizing power using 'naked, shameless, direct, brutal exploitation' (Marx and Engels, 1978, pp. 475-476). In undoing feudal structures, the bourgeoisie produces a system that resolves human worth into exchange value, and generates power for the few at the expense of the working masses. Capital is everywhere, destroying everything, harming everyone. Melodramatic narratives, which identify a villainous force responsible for the suffering they depict, are well suited for revealing and depicting capital's breathtaking violence. Marx and Engels inform the reader that this power has created more massive and colossal productive forces than in all preceding generations combined. It has subjected nature, burst its own fetters and cannibalized all other forms of human relationship.

The bourgeoisie absorbs responsibility for the horrors the authors depict; as the generative force of these injustices, it compels, batters down, creates the world in its own image. The Manifesto's description of villainy makes it easy to champion its overcoming; the bourgeois villain becomes an identifiable target to mobilize against, the singular and clear agent of evil. Marx and Engels may be simplifying power intentionally in the Manifesto in order to shed light on the then-underexamined role of capital in social suffering, and to emphasize the disregarded conditions of the proletariat. In other texts they portray power and capital in significantly more complex ways. Yet presented in this way and in this text, the isolation of capital comes at the price of diminishing other important generative forces of history and social life, and quite possibly of limiting the possibilities for thinking about how to overcome the plight of the working class. This isolation antecedes the left's current problem of narrowing the varied phenomena of power, and may contribute to - though it is not solely responsible for - the determinism that haunts contemporary analysis. With one singular source of accountability, analytic focus is directed at only one aspect of society.

Marx and Engels render in melodramatic detail the suffering of capital's victims: they emphasize the proletariat's dehumanization, as 'rendered 
worthless' by their burdensome and monotonous toils; they are, in body and soul, 'enslaved by the machine' (1978, p. 480, 479). Horrifyingly abject, they are not only without property, but also without supportive family relations, without nation, without law, morality, religion. Stripped of all human connections save capital, 'the proletariat is [Modern Industry's] special and essential product' (1978, p. 482). The Manifesto both denaturalizes economically produced suffering and makes the weak harbingers of emancipation. Because the proletariat is so stripped, their needs are self-less, aligned with all of humanity. The heroic possibility of human emancipation thus lies with them. They become what Karl Löwith calls the 'universal human function of the proletariat', as their self-emancipation will necessarily emancipate all humanity (1993, p. 110). Their abjection is exactly what makes them capable of a world-historic heroism.

After describing the power of villainy and the victimization that it inflicts, the Manifesto moves along the melodramatic narrative trajectory and turns to the victim's heroic overcoming. At the end of section one, Marx and Engels write of the 'decisive hour', the classic heightening of suspense, the race-to-therescue last minute tension that makes melodrama such an affectively engaging mode (1978, p. 481). In their analysis, heroic overcoming will occur by the very victims of capital's cruel and violent logic. Victims become the heroes and perform their own rescue; as Sheldon Wolin writes, 'Not only is revolution to destroy the rule of capital, but the experience is to transform the worker into a heroic actor of epic stature' (2004, p. 434). As the proletariat's numbers grow and its strength concentrates, the future collision between the two classes fulfills the narrative promise, a teleology of revolution providing freedom in/and equality. The melodramatic cycle whereby the injustice of victimization legitimates the violence of heroism is here made manifest in the authorization of revolution.

Combined with the detailing of villainy, this explanation of victimization and heroism intends to engender, viscerally, a new sentiment. It aims to motivate the desire, and the difficult work, for revolutionary change. The horrors endured by the proletariat inform the Manifesto's readers this suffering is unjust, cruel, and yet eradicable. Film theorist Jane Gaines emphasizes melodrama's ability to motivate revolutionary sentiment; she argues, 'Theatrical melodrama has historically been the preferred form of revolutionary periods for precisely its capacity to dichotomize swiftly, to identify targets, to encapsulate conflict and to instill the kind of pride that can swell the ranks of malcontents. Revolutionary melodrama can be depended upon to narrate intolerable historical conditions in such a way that audiences wish to see wrongs 'righted', are even moved to act upon their reaffirmed convictions, to act against tyranny and for the people (Gaines, 1996, pp. 59-60, emphasis added). Gaines, drawing from Sypher, argues that readers of Marx, 'like the 
melodrama audience, see patterns of injustice laid out before us, and we are appalled' (Gaines, 1996, p. 60). Melodrama's affective power, what literary theorist Peter Brooks calls melodrama's 'excess' and Williams calls its 'pathos', makes melodrama so politically powerful for mobilizing large-scale transformations, and can help explain the widespread transnational and transhistorical effects of the Manifesto. The Manifesto ends with a galvanizing call to action: 'The proletarians have nothing to lose but their chains. They have a world to win. WORKING MEN OF ALL COUNTRIES, UNITE!' Having been shown the cruelties and exploitations of industrial capitalism, and asked to reinterpret their own experience through its injustices, the Manifesto's readers are energetically summoned to fight for revolution.

\section{Left Melodrama and Contemporary Political Inquiry}

'Left Melodrama' is a contemporary mode of political critique that aims to incorporate the affective force, explanatory power and moral rightness of the Manifesto by drawing on its generic form. Left melodrama details scenes of unjust victimization, employs cycles of pathos and action, divides social formations into moral binaries and promises a heroic overcoming of injustice and inequality. Unlike the Manifesto, however, it is oriented backward to the loss of the past ideals: left melodrama betrays a longing to re-galvanize political imagination in the way that the Manifesto did in the nineteenth and early twentieth centuries. The contemporary use of melodrama is thus different from the melodrama of the Manifesto, as it is motivated by disavowed loss. Left melodrama aims to recapture the specific losses represented by the Manifesto, and positions the Manifesto to stand as proof of the left's moral virtue, heroic promise and capacity to instigate substantive freedom. When melodrama organizes contemporary critical inquiry in this way, disavowed loss sustains left melancholy in melodramatic form.

Incorporating yet irreducible to manichean polarities, left melodrama is a complex phenomenon: it sustains older leftist critical modes such as monocausality when positing a singular and clear accountability for oppression (usually in the character of a villain); its villainization and victimization of various economic/political positions maintains simplified antagonisms for interpreting social change; its teleology of heroic overcoming of oppression revives the guarantee that leftist theory inevitably guides toward freedom. It even insists that leftist theory is itself an expression of virtue. 'What counts in melodrama' Linda Williams argues, 'is the feeling of righteousness' (2001, p. 44). Although left melodrama is a powerful and dramatic way to expose domination, its melancholic ground limits the comprehension of and response to the domination it aims to unmask. Even as it is an inspiring form of 
argumentation, left melodrama undermines the salience and critical capacity of left critique.

Left melodrama can be found in some of the most important and influential critical theory circulating in academia at the outset of the twenty-first century, including Giorgio Agamben's Homo Sacer and States of Exception, and Michael Hardt and Antonio Negri's collaborative works Empire and Multitude. ${ }^{7}$ Agamben's work interrogates individuals' relationship to the state through the concept of 'bare life': human bodies that become bereft of social value, bodies that can be killed with impunity because their death lacks social or political recognition. The sovereign power of the state is the ultimate arbiter for conferring bare life, as it can except itself from the law and designate bare life, homo sacer, at will. Homo sacer is a provocative and valuable concept for analyzing certain contemporary problems, particularly in States of Exception where it is used to interrogate policies of indefinite detention and the ways in which humans have been subject to state violence while stripped of legal protection and political recognition (Agamben, 2005). Yet for Agamben, critical analysis of bare life is the primary tool to interpret contemporary power. It 'has thus offered the key by which not only the sacred texts of sovereignty but also the very codes of political power will unveil their mysteries' (1998, p. 8). Offering methodological heroism, the very study of homo sacer promises to reveal the analytic truth of our historical moment and the horrors that will occur if it remains unheeded. And it may soon be an omnipotent villain; Agamben warns in Homo Sacer that if left unchecked, state power as the permanent state of exception 'will soon extend itself over the entire planet' (1998, p. 27).

The question that arises from Agamben's inquiry is significant: Is the state really the only arbiter of power in contemporary life, as Agamben seems to claim? ${ }^{8}$ Agamben's left melodrama places responsibility for force and violence on the state, which in his analysis becomes monolithic and omnipotent. State power is in a zero-sum game with individuals, and most contemporary forms of abjection become its effects. He draws clear lines of accountability for the suffering of bare life onto a villain whose motives are transparent: control, dehumanization and domination. Agamben's form of left melodrama marks binaries between homo sacer and the sovereign state, victims and villains, oppressor and oppressed; even as his work aims to dispel antagonistic models with nuanced readings of indistinction, his descriptions instate new binaries in this effort. Agamben's accountability, similarly to Marx and Engels' melodrama, points one sensationalistic finger of blame for social suffering. In some sense, the sovereign state has become capital, the great force of domination leftist scholars can safely and rightly align ourselves, without reservation, against. Perhaps part of Agamben's popularity is that he has given us a new enemy against which to mobilize in opposition.

(C) 2012 Macmillan Publishers Ltd. 1470-8914 Contemporary Political Theory Vol. 11, 2, 130-152 143 
The Nazi death camp functions in this argument as the archetype and epitome of the relationship of sovereignty and bare life, and it models modern individuals' relationship to the state. Agamben's treatment of the camp, which he calls 'the hidden paradigm' of all modern biopower, weakens his analysis of present politics by diminishing the heterogeneity of power, the dynamism of juridicality, the multifaceted and nonlinear directionality of accountability, and the existing forms of nonsovereign politics (1998, p. 123). If political life is captured only by the state of exception, and power is an all-encompassing form of dehumanizing sovereignty - one that seems to apply as much to Nazi death camps as to the suburbs - then all modern individuals become lumped together, categorized without differentiation as pure victims of a villainous entity that has full control over human life. Yet the melancholy of Agamben's left melodrama is not simply the use of earlier analytic methods but the longings that propel their use, especially the desire for unproblematic moral righteousness. Agamben takes pains to assure his readers that homo sacer 'is the protagonist of this book' (1998, p. 27). And later, 'If today there is no longer any one clear figure of the sacred man, it is perhaps because we are all virtually homines sacri' (1998, p. 115).

It is at the juxtaposition of these two claims that the 'hollow core' of this argument shines through. Everyone is a victim of sovereignty; 'we' are all homo sacer, 'the protagonist of this book'. Everyone who aligns politically and morally against the sovereign state, against indefinite detention, is a besieged and virtuous protagonist. Agamben's critique moves solely outward, against a force so nefarious and omnipotent that all can disclaim responsibility for the political horrors his texts depict. This juxtaposition nourishes leftist disavowed desires: we are right, we are beyond reproach, we are against camps, against bare life. As homines sacri, we are innocent victims, free of complicity with oppression, harm and violence effected in our world. Morality is clear, and the discomforting work of self-evaluation is unnecessary, even obsolete. The perhaps unintended effect of this move is that individuals are left somewhat bereft of the capacity to shape society, and in this respect Agamben's melodrama resembles those of Douglas Sirk. His Sirkian narrative offers up victims but denies a readily available hero, and thus undoes the guarantee that freedom will be imminent. Aside from his hopes that humans might create a nonsovereign politics, Agamben's individuals are left to passively wallow in the state of exception, the flip side perhaps to homines sacri's passive protagonism.

This is where Empire, the book hailed as a 'Communist Manifesto for the 21st century' steps in (Žižek, 2001). A different form of left melodrama, Hardt and Negri sew politics, culture and the economy into a complex yet unified tapestry of global society dominated by the machinations of Empire. Empire is 'the political subject that effectively regulates these global exchanges, the sovereign power that governs the world' (Hardt and Negri, 2001, p. xi). It operates as an

144 (C) 2012 Macmillan Publishers Ltd. 1470-8914 Contemporary Political Theory Vol. 11, 2, 130-152 
agent that governs, but supersedes, myriad variations of power and economy in order to permeate varied registers of society and regulate all of them. As the prime mover of contemporary political forces, Empire is 'the idea of a single power that overdetermines them all, structures them in a unitary way, and treats them under one common notion of right that is decidedly postcolonial and postimperialist' (2001, p. 9). The primary antagonism in Empire and Multitude is between empire and the multitude, the villain and the victim of this melodramatic story: the multitude is, like the Manifesto's proletariat, a 'radical counterpower' comprised of marginalized and suffering groups across the globe whose very existence signifies revolutionary promise (2001, p. 66). Hardt and Negri see signs of revolution at the unraveling margins of society. They examine local resistance efforts in different and unaligned sectors of the multitude, and argue that these efforts combined become harbingers of a more total social transformation. With Empire as the 'parasitical' 'single power' of oppression, all forms of challenge presage human emancipation (2004, pp. 336, 9).

The antagonism between empire and multitude carries explanatory power for contemporary society by giving hope and meaning to conditions of domination. It highlights the moral rightness of the dominated, and promises that they will overcome unfreedom. This optimistic analysis and melodramatic rhetoric have captured public imagination, reaching across academic audiences to a broader public readership thirsting for social change. Yet Hardt and Negri's narrative of victimization and heroism, description of a 'single power' as the agent of oppression, and prophetic overcoming of social suffering function like Agamben's analysis to deaden the dynamics of the society they subject to scrutiny. It tidies the messiness, confusions and contingencies of political life, narrows what formations of power and politics can be understood within its terms and revivifies the promise that emancipation is imminent. The aim of Multitude is in part to mobilize the multitude as a new historical force, but as Terrell Carver describes it, 'the enterprise as a whole is much more about updating than it is about announcing anything radically new to the world, as Marx and Engels pointedly did ...' (2006, p. 352). In other words the authors' argument becomes, as Timothy Brennan states, 'everything for newness provided newness is polite enough to appear in familiar forms' (2005, p. 204).

Hardt and Negri's left melodrama is thus an expression of melancholy because of the way its structure is organized by loss. The melodramatic form often harbors a backward focus, in that its critiques of injustice stem from a desire to recapture an idyllic lost past, rather than to postulate a new and unknowable future. The injury that jumpstarts melodramatic narratives often marks the loss of a past state of virtue that will be recaptured by righting the victim's injury and re-establishing a prior state of moral rightness. In Peter Brooks' analysis, melodramas aim to re-establish a virtuous world that was 
seemingly destroyed by villainy, in which goodness, rightness and truth are easily identifiable and ever-present; this is the lost promise that left melodrama aims to recover. Referring to melodrama's backward gaze, film scholar Christine Gledhill contends, 'Melodrama's challenge lies not in confronting how things are, but rather in asserting how things ought to be. But since it operates within the frameworks of the present social order, melodrama conceives "the promise of human life" not as a revolutionary future, but as a return to a "golden past": less how things ought to be then how they should have been' (1988, p. 21). For Gledhill, melodramas often dramatize the forces of revolution but from within the boundary of the dominant social/economic/ political order in which they are deployed. In this sense, melodramatic idealizations of the past eventually recoil social critique and reassert the status quo. Timothy Brennan captures this dynamic in the quote above, in how Empire's premise of radical transformation in the future looks suspiciously like the Manifesto's nineteenth-century revolutionary promise.

In this vein, Empire demonstrates a form of political analysis too rooted in the disavowed loss of past promises to fully grasp the newness of the present. Its left melodrama incorporates the Manifesto's emancipatory guarantee, while refusing to evaluate the methods, promises and style it uses to secure that guarantee. Indeed, Empire may even deaden the Manifesto by turning its forceful analysis into the empty papier-mâché fist that Benjamin so feared. Though they take into account the historic particularities of contemporary globalization, current political events and recent identity politics, Empire and Multitude still search for a past ideal to ground their vision of the future. Using the Manifesto as that ideal, they put forth immanent revolution, the moral virtue of their protagonists/readers, clear lines of social accountability, and as John Brenkman puts it, a 'root thesis' (Brenkman, 2007, p. 66), left theory's continual attempt (a melodramatic one, I would submit) to find one root cause that carries the explanatory power for all social ills. The lost ideal, therefore, is less the possibility of freedom or the Manifesto per se, than the guarantee that freedom is immanent and that moral virtue is necessarily conferred upon those who desire it.

By lumping together very different groups into the multitude - including its readers, including us - and then positing that undifferentiated and unstratified whole as the hero of humanity, Empire perpetuates the most problematic aspect of left melodrama. Like Agamben's analysis, in which the reader is likened to homo sacer, Hardt and Negri's analysis implicitly encourages its readers to identify as a member of the multitude. ${ }^{9}$ The left melodrama of both analyses places its readers as victims of the horrifying forces they depict. The melodramatic trope that links victimization to virtue works here to disclaim responsibility for any of the injustices depicted in these texts. The work of reassessing one's own investments and responses to inequality and 
oppression, including those to which one may be contributing, even unintentionally, is now rendered unnecessary. The moral certainty of left melodrama and the inseparability of marginalization, victimhood and virtue are, in part, a refusal of self-critique, a refusal that Stuart Hall insists has contributed to the debilitating weakness of left politics.

\section{Reworking Left Melodrama?}

It is important to note that the Manifesto's melodrama operates differently from contemporary left melodrama in two ways. First, the sufferers in the Manifesto's melodramatic story are not free of responsibility for creating or overcoming injustice. The agency of heroic emancipation is in a complex relationship to teleology: revolution is forthcoming but requires the action of the workers and the communist party. The overcoming of capital is both inevitable and yet must be nourished by collective political action. Both the weapons that will destroy capitalism, and the people who wield them, are called into being by capitalist forces. While the final source of emancipation is not fully worked out in the Manifesto, or perhaps it is more accurate to say that the process of emancipation is purposely ambiguous and multifaceted, it still relies in part upon the agency of the dispossessed and the communist party. After all, the bourgeoisie does not provide its own grave, but instead its own grave-diggers.

Second, the analysis in the Manifesto, unlike left melodrama, is not motivated by loss. Marx and Engels uproot melodrama's conventional backward-looking inspiration and forcibly turn its focus forward, to an unknown and unknowable future. The frustration and excitement of the text, indeed its necessity, is that it intentionally does not flesh out what a nonbourgeois, communist, post-revolutionary future will look like. For Marx and Engels, any description of the future would inevitably be colored by the framework of the present, and thus would diminish the possibility of motivating truly radical change. In not charting the future, therefore, they choose not to limit its transformative possibilities. This is not to say that Marx and Engels understand the future to have limitless possibility, but that they make a strategic effort not to offer a systematic vision of the post-revolutionary future. Gledhill suggests that most melodramas are motivated by a normative vision of the past that often serves to structure and limit future visions. Marx and Engels, by contrast, refuse to posit an ideal past that can be recaptured. They interpret history through cycles of violence that staunch nostalgia for any past epoch. Instead, the Manifesto only gestures to the eventual dissolution of economic inequality, and allows the vision of the future to be open-ended, unconstrained by the limitations of the present. 
This essay reads melodrama in the Manifesto in order to draw out why melodrama may appeal to certain segments of contemporary political theory as a mode of analysis. Of course reading the Manifesto through melodramatic does not, could not, exhaust the varied cultural modes and rhetorical devices that structure its logic and shape its worldwide effects; to claim the Manifesto as fully explainable in this way would be its own form of melodrama. Much of the text does not conform to melodramatic conventions, and even disrupts its melodramatic elements: its forward-looking vision, its refusal to ground critique in the loss of a past ideal, its ambiguity in detailing the agency of heroic emancipation, and the proletariat's complex relation to the overcoming of the villainy of capital - as both its conqueror and inheritor - all disrupt conventional melodramatic tropes. The Manifesto is not a melancholic text, and refuses to generate a lost past ideal as a model for the future. Yet the current re-uptake of its melodrama works in this way. While this certainly does not mean that contemporary thinkers should refuse the inspiration of the Manifesto, it suggests that melancholic incorporation of the Manifesto's melodramatic tenets limits the critical salience of contemporary leftist theory. Left melodrama appropriates the Manifesto's style in order to hold on to the failed guarantee of immanent freedom, and to reassure the present left of its unwavering moral rightness in the face of its weakness and defeats.

I would like to be clear about my claims: I think it is imperative to diagnose and rectify conditions of social, political and economic violence, injustice and inequality and name their sources of accountability. And any strong push for real social transformation must be motivated and galvanized by moral visions of what is good and right. I am certainly not arguing that extraordinary political, economic and socially produced suffering does not exist in contemporary life, that moral goodness is impossible or that clarity must be forsaken in political inquiry. Each of these claims would be a melodramatic counter to what I hope to diagnose as a particular problem: the intellectual and political dilemmas that arise when the Manifesto's melodramatic tropes shape contemporary political explanation, when its tenets become normalized in current intellectual inquiry, when its narrative promises become future visions of heroic emancipation. In this vein, I am wary that this essay could itself be interpreted as a product of left melancholy, read as a critique of left melodrama from a position of melancholic self-flagellation against the internalized lost object of moral promise. My hope is that, by attempting to identify the operations of some of these losses, this essay derives from a different place, in which the very working through of loss marks an effort to transform it, in which the refusal to grant moral purity to cherished canonical texts, key modes of inquiry and firm political identifications keeps them open to examination.

There are certainly examples of contemporary political theory that align with the self-critical working-though of left melancholy. They include political 
critique that avows the loss of moral righteousness and sees it as mark of strength that can engender innovative and vital political diagnoses; ${ }^{10}$ work that emphasizes the tragic dimension of politics, highlighting the inescapable losses, and losers, inherent to all forms of political inquiry and collective selfgovernance; scholarship in which leftist individuals, collectives and political groups are partly accountable for inequality and injustice and also have the potential to change them; and scholars that accept a multiplicity of coexisting visions for radical political, economic and social change in part by acknowledging the partial quality of their own assertions. ${ }^{11}$ These modes of theory address the precise problem of melancholy because they explicitly avow responsibility, loss or a refusal of self-purity as starting conditions for critical interrogation. While no single approach could be a panacea for the leftist theory's current dilemmas and each of these options is limited in its own right, one thing is clear: recourse to left melodrama deepens the deadening work of left melancholy and intensifies the pressing challenges that left politicaltheoretical work aims to expose, scrutinize and diminish.

\section{Acknowledgements}

The author would like to thank Wendy Brown, Judith Butler, Sam Chambers, The DC Queer Studies Consortium, Steven Johnston, Joel Olson, Matthew Scherer, Suzanne Stewart-Steinberg, Neve Gordon, Elizabeth Weed, Linda Williams and two anonymous reviewers for their constructive comments and conversations on this essay.

\section{Notes}

1 Melancholy, for Benjamin, is always a product of the historical moment it inhabits. Its operations and source of sadness are temporally shifty; indeed, it is one aim of the Origins of German Tragic Drama to investigate the constellation of interpretations for how melancholy has been differently situated. Benjamin connects 'Left Melancholy' to the work in German Tragic Drama when writing that left melancholy is the latest development of 2000 years of melancholia. Left Melancholy's deadening of revolutionary reflexes is inescapably situated in, and a product of, its time period. Perhaps, then, the making dead of live things provides an accurate reflection of the historical moment Benjamin analyzes: it is the work of commodification and alienation, of capital's turning the world and its inhabitants into dead objects. Left Melancholy, possibly, encapsulates this turn, revealing the true story of the violence in which it is situated, of a life lived through processes that turn all things into commodities and numbers, that render live things dead for efficiency and profit.

2 I retain Freud's term 'object' to describe what has been lost in left melodrama because the term attends to the psychic dimension of the losses I examine. I therefore use 'object' as specific reference to the psychoanalytic valence of melancholy, and do not intend it to mark a broad or quotidian use of the term.

(C) 2012 Macmillan Publishers Ltd. 1470-8914 Contemporary Political Theory Vol. 11, 2, 130-152 149 
3 The Manifesto did not function as a worldwide spark for radical social transformation until years after its initial publication, yet its eventual influence makes it, perhaps, the most galvanizing work of political theory in western modernity.

4 For the purposes of this article, I utilize a core set of conventions that generally are present throughout melodrama's different iterations, while being attentive to how melodrama manifests differently in different texts and historical moments, in particular noting its differences in the Manifesto, Empire and Homo Sacer. As Neale (1993) and Williams (1998) among others note, melodrama references a set of generic conventions yet it also shifts and evolves; the term 'melodrama' means different things at different historic moments and social spaces, as can be demonstrated by its varied definitions in Rousseau's origination of the term, its use in the American film industry in the 1920s, and again in feminist film and theater studies in the 1980s.

5 Sergei Eisenstein's classic film Battleship Potemkin (1925) is a paradigmatic example of how melodrama quickly transitioned from Soviet theater to film.

6 For the purpose of this essay I leave to one side ongoing and important debates about the different roles and attributions of Marx and Engels in crafting the Manifesto. For a compelling analysis of Marx and Engels's various roles, see Carver (1999, pp. 22-23).

7 I am not suggesting that these books could be exclusively explained through recourse to melodrama, but instead intend to show what can be illuminated when we read their projects as melodrama.

8 And a similar question would be: Is the Bush administration the main line of accountability for the state of emergency after 9/11, as States of Exception implies? Agamben (2005, p. 22) writes, 'President Bush's decision to refer to himself constantly as the "Commander in Chief" after 11 September 2001, must be considered in the context of this presidential claim to sovereign powers in emergency situations. If, as we have seen, the assumption of this title entails a direct reference to the state of exception, then Bush is attempting to produce a situation in which the emergency becomes the rule, and the very distinction between peace and war (and between foreign and civil war) becomes impossible'.

9 On this point see Nealon (2009, p. 41): 'Though [Hardt and Negri] caution that this socialization does not mean that all struggles are alike, or that all exploitation is equally intense, their stance clearly makes room for the affect-workers of the northern literary academy to imagine themselves in alliance with the exploited of the global south'.

10 In 'Occupying Hannah' Jones (2008) queries whether she could, perhaps, have been as banal as Eichmann, and thus insists on challenging her own sense of moral righteousness and drawing from this insistence to galvanize social change. For a pointed critique of left righteousness see Dean (2009).

11 See Coles (2005), Connolly (1995) and Johnston (2007); Brown (2001), Kaufman-Osborn (2008), Puar (2007) and Wolin (2008); Borradori (2004), Butler (1997, 2004), Gilroy (2004) and Thiem (2008).

\section{References}

Agamben, G. (1998) Homo Sacer: Sovereign Power and Bare Life, Translated by D. Heller-Roazen. Stanford, CA: Stanford University Press.

Agamben, G. (2005) States of Exception, Translated by K. Attell. Chicago, IL: University of Chicago Press.

Anker, E. (2005) Villains, victims and heroes: Melodrama, media and 9/11. Journal of Communication 88(1): 22-37.

150 (C) 2012 Macmillan Publishers Ltd. 1470-8914 Contemporary Political Theory Vol. 11, 2, 130-152 
Benjamin, W. (2003) The Origin of German Tragic Drama, Translated by J. Osborne. London: Verso.

Benjamin, W. (2005) Left-wing melancholy. In: M. Jennings, H. Eiland and G. Smith (eds.), Walter Benjamin: Selected Writings, Vol. 2., pt. 1. Cambridge, MA: Harvard University Press.

Bennett, J. and Shapiro, M. (eds.) (2002) Introduction. The Politics of Moralizing. London: Routledge.

Borradori, G. (2004) Philosophy in a Time of Terror: Dialogues with Jurgen Habermas and Jacques Derrida. New York: Columbia University Press.

Brenkman, J. (2007) Cultural Contradictions of Democracy: Political Thought since September 11. Princeton, NJ: Princeton University Press.

Brennan, T. (2005) Wars of Position: Cultural Politics of Left and Right. New York: Columbia University Press.

Brooks, P. (1995) The Melodramatic Imagination: Balzac, Henry James, Melodrama and the Mode of Excess. New Haven, CT: Yale University Press.

Brown, W. (1999) Resisting left melancholy. Boundary 2 26(3): 19-27.

Brown, W. (2001) Politics Out of History. Princeton, NJ: Princeton University Press.

Buckley, M. (2006) Tragedy Walks the Streets: The French Revolution in the Making of Modern Drama. Baltimore, MD: Johns Hopkins University Press.

Butler, J. (1997) The Psychic Life of Power: Essays in Subjection. Stanford, CA: Stanford University Press.

Butler, J. (2004) Precarious Life: The Powers of Mourning and Violence. London: Verso.

Carver, T. (1999) The Engels-Marx question. In: M. Steger and T. Carver (eds.), Engels after Marx. University Park, PA: Pennsylvania State University Press.

Carver, T. (2006) Less than full Marx. Political Theory 34(3): 351-356.

Coles, R. (2005) Beyond Gated Politics: Reflections on the Possibility of Democracy. Minneapolis, MN: University of Minnesota Press.

Connolly, W.E. (1995) The Ethos of Pluralization. Minneapolis, MN: University of Minnesota Press.

Dean, J. (2009) Democracy and Other Neoliberal Fantasies. Durham, NC: Duke University Press.

Elsaesser, T. (1987) Tales of sound and fury: Observations of the family melodrama. In: C. Gledhill (ed.), Home is Where the Heart is: Melodrama and the Woman's Film. London: British Film Institute.

Freud, S. (1959) Mourning and Melancholia [1917]. In: J. Strachey (ed.), Collected Papers, Vol. 4. Translated by J. Riviere. New York: Basic Books.

Freud, S. (1990) Group Psychology and Analysis of the Ego 1922, Translated by J. Strachey. New York: W.W. Norton.

Gaines, J. (1996) The Melos of Marxist theory. In: D.E. James and R. Berg (eds.), The Hidden Foundation: Cinema and the Question of Class. Minneapolis, MN: University of Minnesota Press.

Gerould, D. (1994) Melodrama and revolution. In: J. Bratton, J. Cook and C. Gledhill (eds.), Melodrama: Stage, Picture, Screen. London: British Film Institute.

Gilroy, P. (2004) Postcolonial Melancholia. New York: Columbia University Press.

Gledhill, C. (ed.) (1987) Introduction. Home is Where the Heart is: Studies in Melodrama and the Woman's Film. London: British Film Institute.

Hall, S. (1988) Hard Road to Renewal: Thatcherism and Crisis of the Left. London: Verso.

Hardt, M. and Negri, A. (2001) Empire. Cambridge, MA: Harvard University Press.

Hardt, M. and Negri, A. (2004) Multitude. Cambridge, MA: Harvard University Press.

Johnston, S. (2007) The Truth about Patriotism. Durham, NC: Duke University Press.

Jones, K.B. (2008) Occupying Hannah. Unpublished paper presented to the 2008 Western Political Science Association Feminist Theory Working Group.

(C) 2012 Macmillan Publishers Ltd. 1470-8914 Contemporary Political Theory Vol. 11, 2, 130-152 151 
Kaufman-Osborn, T. (2008) We are all torturers now: Accountability after Abu-Ghraib. Theory and Event 11(2).

Löwith, K. (1993) Max Weber and Karl Marx. London: Routledge.

Marx, K. and Engels, F. (1978) The manifesto of the communist party. In: R. Tucker (ed.), The Marx-Engels Reader. New York: W.W. Norton.

Mulvey, L. (2009) Visual and Other Pleasures. New York: Palgrave Macmillan.

Neale, S. (1993) Melo talk: On the meaning and use of the term 'melodrama' in the American trade press. The Velvet Light Trap 32: 66-89.

Nealon, C. (2009) Reading on the left. Representations 108: 22-50.

Pryzbos, J. and Gerould, D. (1980) Melodrama in the Soviet theater. In: D. Geroud (ed.), Melodrama. New York: New York Literary Forum 7.

Puar, J. (2007) Terrorist Assemblages: Homonationalism in Queer Times. Durham, NC: Duke University Press.

Rousseau, J.J. (1990) Lettre a M. Burney, sur la musique, avec fragments d' Observations sur Alceste [1774]. In: R. Masters (ed.), Collected Writings of Rousseau, Vol. 7. Hanover, NH: Dartmouth College, pp. 491-505.

Schmitt, C. (1996) The Concept of the Political, Translated by G. Schwab. Chicago, IL: University of Chicago Press.

Sypher, W. (1948) The aesthetic of revolution: The Marxist melodrama. Kenyon Review 10(3): $431-441$.

Thiem, A. (2008) Unbecoming Subjects. Bronx, NY: Fordham University Press.

Williams, L. (1998) Melodrama revised. In: N. Browne (ed.), Refiguring Film Genres. Berkeley, CA: University of California Press.

Williams, L. (2001) Playing the Race Card: Melodramas of Black and White from Uncle Tom to OJ Simpson. Princeton, NJ: Princeton University Press.

Wolin, S. (2004) Politics and Vision. Princeton, NJ: Princeton University Press.

Wolin, S. (2008) Democracy Incorporated: Managed Democracy and the Specter of Inverted Totalitarianism. Princeton, NJ: Princeton University Press.

Žižek, S. (2001) Have Michael Hardt and Antonio Negri rewritten the communist manifesto for the twenty-first century? Rethinking Marxism 13(3-4): 190-198. 